\title{
TITLE IX APPLIES TO EMPLOYMENT DISCRIMINATION
}

In 1972 Congress passed Title IX of the Education Amendments. ${ }^{1}$ The main provision, section 901(a), provides that "No person in the United States shall, on the basis of sex, be excluded from participation in, be denied the benefits of, or be subjected to discrimination under any education prograin or activity receiving Federal financial assistance ....."2

Acting under its statutory authority to promulgate regulations under Title IX, ${ }^{3}$ the Department of Health, Education, and Welfare (HEW) issued regulations that include prohibitions of sex-based employment discrimination. ${ }^{4}$ HEW's authority to regulate in this area has been challenged in several recent cases on the ground that section 901 protects only students and other direct beneficiaries of federal assistance, and not employees. Only the Court of Appeals for the Second Circuit, in North Haven Board of Education v. Hufstedler, ${ }^{5}$ has upheld the validity of the regulations. ${ }^{6}$ The North Haven decision created a conflict ainong the courts of appeals that has left the Department of

1. Title IX of the Education Amendments of 1972, $\$ \S 901-906,20$ U.S.C. $\S \S 1681-1688$ (1976).

2. 20 U.S.C. $\S 1681(a)$ (1976).

3. Id. $\S 1682$, which provides in part:

Each Federal department and agency which is empowered to extend Federal financial assistance to any education program or activity, by way of grant, loan, or contract other than a contract of insurance or guaranty, is authorized and directed to effectuate the provisions of section 1681 of this title with respect to such program or activity by issuing rules, regulations, or orders of general applicability which shall be consistent with achievement of the objectives of the statute authorizing the financial assistance in connection with which the action is taken.

4. 45 C.F.R. $\$ \S 86.51-61$ (1980). Jurisdiction over educational matters was transferred from HEW to the Department of Education on May 4, 1980. 20 U.S.C.A. $\S 1232$ (West Supp. 1980) (official comment). The new department reissued the regulations in identical form. 34 C.F.R. $\$ \S 106.51-.61$ (1980).

5. 629 F.2d 773 (2d Cir. 1980), cert. granted sub nom. North Haven Bd. of Educ. v. Bell, 101 S. Ct. 1345 (1981). Cases holding the regulations invalid include Seattle Univ. v. HEW, 621 F.2d 992 (9th Cir.), cert. granted sub nom. Department of Educ. v. Seattle Univ., 101 S. Ct. 563 (1980); Romeo Community Schools v. HEW, 600 F.2d 581 (6th Cir.), cert. denied, 444 U.S. 972 (1979); Junior College Dist. of St. Louis v. Califano, 597 F.2d 119 (8th Cir.), cert. denied, 444 U.S. 972 (1979); Islesboro School Comm. v. Califano, 593 F.2d 424 (1st Cir.), cert. denied, 444 U.S. 972 (1979); Auburn School Dist. v. HEW, 19 Fair Empl. Prac. Cas. 1504 (D.N.H. 1979), appeal dismissed, No. 79-1261 (1st Cir. 1980); Board of Educ. v. HEW, 19 Fair Empl. Prac. Cas. 457 (N.D. Ohio 1979); University of Toledo v. HEW, 464 F. Supp. 693 (N.D. Ohio 1979).

6. 629 F.2d at 786 . 
Education ${ }^{7}$ in great doubt about its role under Title IX. ${ }^{8}$

This note argues that HEW's Title IX implementing regulations are valid. After reviewing the relevant cases, the note examines the scope of Title IX, its legislative history, and the remedies it creates, concluding that Congress did intend Title IX to prohibit employment discrimination in educational institutions receiving federal financial assistance.

\section{Creation of the Conflict}

The Courts of Appeals for the First, 9 Sixth, ${ }^{10}$ Eighth, ${ }^{11}$ and Ninth ${ }^{12}$ Circuits have held that HEW does not have the authority under Title IX to regulate employment practices. In Islesboro School Committee v. Califano, ${ }^{13}$ the first case to consider HEW's Title IX regulations, the First Circuit declared invalid an HEW regulation requiring employers to pay disability benefits to employees on pregnancy leave. ${ }^{14}$ The court reasoned that the "plain language" of section 901 does not encompass employees. ${ }^{15}$ Noting that the statute does not expressly exclude einployees, ${ }^{16}$ however, the court examined the legislative history of Title IX, which consists almost exclusively of oral statements by the Act's sponsor, Senator Bayh. The court discounted the importance of these stateinents, reasoning that oral discussion is too imprecise to be

7. The Department of Education has replaced HEW as the agency that enforces Title IX. See note 4 supra.

8. To avoid wasting resources, the Department of Education's Office for Civil Rights has instructed its regional offices to proceed only when "(1) . . . the principal purpose of the federal assistance in question is to provide employment or (2) ... the allegedly discriminatory employment practice may have a discriminatory impact upon students or other direct beneficiaries of the federal assistance." Petitioner's Brief for Certiorari at 11 n.4, Seattle Univ. v. HEW, 621 F.2d 992 (9th Cir.), cert. granted sub nom. Department of Educ. v. Seattle Univ., 101 S. Ct. 563 (1980).

9. Islesboro School Comm. v. Califano, 593 F.2d 424 (1st Cir.), cert. denied, 444 U.S. 972 (1979).

10. Romeo Community Schools v. HEW, 600 F.2d 581 (6th Cir.), cert. denied, 444 U.S. 972 (1979).

11. Junior College Dist. of St. Louis v. Califano, 597 F.2d 119 (8th Cir.), cert. denied, 444 U.S. 972 (1979).

12. Seattle Univ. v. HEW, 621 F.2d 992 (9th Cir.), cert. granted sub nom. Department of Educ. v. Seattle Univ., 101 S. Ct. 563 (1980).

13. 593 F.2d 424 (1st Cir.), cert. denied, 444 U.S. 972 (1979).

14. 45 C.F.R. \& 86.57(c) (1980), which provides:

A recipient shall treat pregnancy, childbirth, false pregnancy, termination of pregnancy, and recovery therefron and any temporary disability resulting therefrom as any other temporary disability for all job related purposes, including commencement, duration and extensions of leave, payment of disability income, accrual of semiority and any other benefit or service, and reinstatement, and under any fringe benefit offered to employees by virtue of employment.

15. 593 F.2d at 426 . For a contrary view, see text accompanying notes $43-48$ infra.

16. 593 F.2d at 426. 
taken hiterally. ${ }^{17}$ The court ignored the substantive content of the legislative history ${ }^{18}$ and later written clarifications of the legislative history by Senator Bayh. ${ }^{19}$

Shortly after Islesboro, the Sixth Circuit, in Romeo Community Schools $v . H E W, 20$ examined the language of section $901^{21}$ and held that the words "no person" are limited by the later language of the statute so that the section covers only persons discriminated against "under any education program or activity receiving Federal financial assistance."22 The court assumed that this language excludes all einployees, even though the Islesboro court, upon which Romeo rehed heavily, ${ }^{23}$ recognized that some teachers are direct beneficiaries of federal aid and could therefore be protected by the statute. ${ }^{24}$ To buttress its conclusion, the Romeo court poimted out that other federal statutes were designed to deal with einployment discrimination, ${ }^{25}$ and that it was therefore unlikely that Congress intended to create an additional remedy in section $901 .^{26}$

The other courts that have invalidated the regulations have rehed heavily on the Islesboro and Romeo decisions. The Eighth Circuit, for example, stated, "[T]he First Circuit in Islesboro . . . has thoroughly addressed this question. We agree with the First Circuit's disposition of the issue and adopt the decision of that court."27 The Ninth Circuit refused to address the substantive issues, instead stating that "[e]ach argument raised by HEW on this appeal has been thoroughly addressed by [the courts in earher cases]. We agree with their decisions, and we find it unnecessary to add to their discussions."28 A nuunber of district courts have also struck down the regulations, ${ }^{29}$ by relying on

17. Id. at 427.

18. See text accompanying notes 105-13 infra.

19. See text accompanying notes 114-20 infra.

20. 600 F.2d 581 (6th Cir.), cert. denied, 444 U.S. 972 (1979).

21. For the text of section 901, see text accompanying note 2 supra.

22. 600 F.2d at 584 (quoting section 901, 20 U.S.C. $\$ 1681$ (1976)).

23. See 600 F.2d at 585 .

24. $593 \mathrm{~F} .2 \mathrm{~d}$ at 426.

25. The court explained that there is a "mosaic of federal statutes" to protect women and minorities, imcluding Title VII, 42 U.S.C. $\$ 2000$ e (1976), and the Equal Pay Act, 29 U.S.C. $\S 213$ (a) (1976). 600 F.2d at 584.

26. 600 F.2d at 584. See text accompanying notes $129-41$ infra.

27. Junior College Dist. v. Califano, 597 F.2d 119, 121 (8th Cir.), cert. denied, 444 U.S. 972 (1979).

28. Seattle Univ. v. HEW, 621 F.2d 992, 994 (9th Cir.), cert. granted sub nom. Department of Educ. v. Seattle Univ., 101 S. Ct. 563 (1980).

29. Grove City College v. Harris, 500 F. Supp. 253 (W.D. Pa. 1980); Auburn School Dist. v. HEW, 19 Fair Empl. Prac. Cas. 1504 (D.N.H. 1979), appeal dismissed, No. $79-1261$ (1st Cir. Jan. 16, 1980); Board of Educ. v. HEW, 19 Fair Enupl. Prac. Cas. 457 (N.D. Ohio 1979); University of Toledo v. HEW, 464 F. Supp. 693 (N.D. Ohio 1979). 
the reasoning of other courts. ${ }^{30}$ Because only a few courts have independently evaluated the proper scope of section 901,31 the weight of authority against the HEW regulations is actually less than it nay seem.

The Court of Appeals for the Second Circuit in North Haven Board of Education v. Hufstedler ${ }^{32}$ has recently revived the controversy over the validity of HEW's regulations by holding that the Departinent of Education may regulate einployment practices of educational institutions receiving federal assistance under Title IX. Though aware of the many decisions invalidating the regulations, ${ }^{33}$ the court made its own in-depth analysis of the issue. Speaking for the court, Judge Oakes relied primarily on congressional intent to interpret section 901:

[O]ur reading of the statutory scheme leads us to conclude that Congress intended HEW to have available the potent remedy of fund withdrawal to ensure complance with the prohibition against sex discrimination im employment rather than rely solely on the important, but usually piecemeal, sanctions available to aggrieved employees under Title VII and the Equal Pay Act. ${ }^{34}$

The court based its conclusion on statements by Title IX's sponsor, Senator Bayh, ${ }^{35}$ and on implications drawn from express exceptions created in Title IX for parochial schools and military academies, exceptions which were apparently designed to exclude the einployinent practices of those institutions from the purview of Title IX. ${ }^{36}$

\section{The Provisions of TrtLe IX}

\section{A. The Specific Language of Section 901(a).}

The langnage of section 901(a), defining the scope of Title IX, is

30. See, e.g., Board of Educ. v. HEW, 19 Fair Empl. Prac. Cas. 457 (N.D. Ohio 1979) (adopting the reasoning of University of Toledo v. HEW, 464 F. Supp. 693 (N.D. Ohio 1979)); University of Toledo v. HEW, 464 F. Supp. 693 (N.D. Ohio 1979) (relying upon Romeo Community Schools v. HEW, 600 F.2d 581 (6th Cir.), cert. denied, 444 U.S. 972 (1979) and Junior College Dist. v. Califano, 597 F.2d 119 (8th Cir.), cert. denied, 444 U.S. 972 (1979)).

31. Those cases squarely addressing the issue are Roineo Community Schools v. HEW, 438 F. Supp. 1021 (E.D. Mich.), aff'd, 600 F.2d 581 (6th Cir. 1977), cert. denied, 444 U.S. 972 (1979) and Islesboro School Comm. v. Califano, 593 F.2d 424 (1st Cir.), cert. denied, 444 U.S. 972 (1979).

32. 629 F.2d 773 (2d Cir. 1980), cert. granted sub nom. North Haven Bd. of Educ. v. Bell, 101 S. Ct. 1345 (1981).

33. 629 F.2d at $775 \&$ n.2.

34. Id. at 785 .

35. Id. at 779-82.

36. Id. at 782. The position of the Court of Appeals for the Second Circuit is supported by dictun in the Court of Appeals for the Fifth Circuit's decision in Dougherty County School Sys. v. Harris, 622 F.2d 735 (5th Cir. 1980). The Dougherty court, though holding invalid the regulations actually promulgated, concluded that the language of section 901 is broad enough to cover employees of educational institutions. Id. at 738 . 
extremely broad. ${ }^{37}$ For example, section 901(a) does not use the word "student"; it uses "person," a word broad enough to encompass not only students, but also teachers and other staff. ${ }^{38}$ Nevertheless, in Brunswick School Board v. Califano, ${ }^{39}$ the district court expressly applied the statutory construction doctrine of ejusdem generis, that a general provision or word of a statute ("no person") is controlled and limited by subsequent statutory language more specific in scope. ${ }^{40}$ The court stated that "the specific words of $\S 901$ unmistakably delineate the direct beneficiaries of or participants in federally aided education programs as those whoin the statute seeks to protect."41 In affirming Brunswick, the Islesboro court agreed with this interpretation and added that section 901, "on its face, is aimed at the beneficiaries of the federal momies, i.e., either students . . . or teachers engaged in special research being funded by the United States government."42

These decisions incorrectly restrict the scope of section 901 by limiting its coverage to direct beneficiaries and participants. Arguably, as HEW has asserted, the fact that section 901(a) uses the word "person" indicates that it is not limited to any specific class of persons, but instead is limited only by the statute's nine express exceptions..$^{43}$ Or, as HEW has also argued, the word "person" under section 901 is meant to be modified only by the three subsequent phrases: "person" includes anyone who is "excluded from participation in, . . . demed the benefits of, or . . . subjeeted to discrimination under any education program or activity receiving Federal financial assistance."44 In dictum, the court in Dougherty County School System v. Harris ${ }^{45}$ approved sueh a reading, poimting out that "[a] female teacher whose salary is defrayed by federal funds and who is paid less than a male teacher in the same prograin is subjected to discrimination under the program."46 The Brunswick court, failing to consider an entire category of persons protected by the language of the statute -employees subjected to discrimination under education programs-thus incorrectly limits the meaning

37. See text accompanying note 2 supra.

38. See Dougherty County School Sys. v. Harris, 622 F.2d 735, 737-38 (5th Cir. 1980).

39. 449 F. Supp. 866 (D. Me. 1978), affd sub nom. Islesboro School Comm. v. Califano, 593 F.2d 424 (1st Cir.), cert. denied, 444 U.S. 972 (1979).

40. 449 F. Supp. at 870. See, e.g., Wedding v. Wingo, 483 F.2d 1131, 1135 (6th Cir. 1973); 2A

J. SUTHERLAND, StatuTES AND Statutory Construction $\$ 47.17$ (4th ed. C. Sands 1973).

41. 449 F. Supp. at 870.

42. 593 F.2d at 426 .

43. See North Haven Bd. of Educ. v. Hufstedler, 629 F.2d 773, 777 (2d Cir. 1980), cert. granted sub nom. North Haven Bd. of Educ. v. Bell, 101 S. Ct. 1345 (1981).

44. 629 F.2d at 777 (quoting 20 U.S.C. $\& 1681$ (1976)).

45. 622 F.2d 735 (5th Cir. 1980).

46. Id. at 738 . 
of "no person"; and the Islesboro court, affirming Brunswick, acted too hastily in broadly asserting that "[n]othing in the statute suggests that it should be construed to extend to einployees qua einployees . . . ."47

Moreover, although the language of section 901(a) is ambiguous, ${ }^{48}$ an analysis of the exceptions to section 901 also reveals that the section was intended to reach einployees. ${ }^{49}$

\section{B. The Exceptions to Section 901.}

Section 901(a) creates nine express exceptions to its prohibitions. ${ }^{50}$ None of these exceptions makes Title IX inapplicable to employees of educational institutions; implicitly this omission suggests that Title IX does cover employees.

The Islesboro court asserted that because the exceptions do not mention employees, the statute was not designed to deal with employees. 51 All of the exceptions, the court pointed out, "deal witll student admissions or activities of a student nature, e.g., 'beauty' pageants, social fraternities and sororities, Boys State conference, Girls Nation con-

47. 593 F.2d at 426 .

48. See North Haven Bd. of Educ. v. Hufstedler, 629 F.2d 773, 777 (2d Cir. 1980), cert. granted sub nom. North Haven Bd. of Educ. v. Bell, 101 S. Ct. 1345 (1981).

49. See generally Hearings on H.R. 7152 Before the House Comm. on Rules, 88th Cong., 2d Sess. 198 (1964) [hereinafter cited as Hearings] (remarks of Rep. Poff, an opponent of employment regulations under Title VI, who noted that the words "subjected to discrimination under" in section 601 of Title VI could cover employees).

50. 20 U.S.C. \& 1681(a) (1976). These exceptions mclude the following:

(2) Educational institutions commencing planned change in admissions

in regard to admissions to educational institutions, this section shall not apply (A) for one year from June $23,1972, \ldots$ in the case of an educational institution which has begun the process of changing from being an institution which admits ouly students of one sex to being an institution which admits students of both sexes, but only if it is carrying out a plan for such a change which is approved by the Commissioner of Education or (B) for seven years from the date an educational institution begins the process of changing from being an institution which admits only students of only one sex to being an institution which admits students of both sexes, but only if it is carrying out a plan for such a change which is approved by the Commissioner of Education, whichever is the later;

(3) Educational institutions of religious organizations with contrary religious tenets this section shall not apply to an educational institution which is controlled by a rehigious organization if the application of this subsection would not be consistent with the religious tenets of such organization; marine

(4) Educational institutions training individuals for military services or merchant this section shall not apply to an educational institution whose primary purpose is the training of individuals for the military services of the United States, or the merchant marine;

(5) Public educational institutions with traditional and continuing admissions policy in regard to admissions this section shall not apply to any public institution of undergraduate higher education which is an institution that traditionally and continually from its establishment has had a policy of admitting only students of one sex . . . .

Id.

51. 593 F.2d at 426 . 
ference, father-son and mother-daughter activities."52 Taking the same position, the court in Romeo Community Schools v. HEW $W^{53}$ asserted: "It may be fairly assumed that the exceptions relate to students because students are the subject of [\$901]; that is, the exceptions deal with the same subject inatter as that covered generally by the preceding language." 54 HEW has argued, on the other hand, that none of the nine express exceptions removes employment froin section 901's coverage, indicating that Congress did not intend to so restrict the statute's scope. $55 \mathrm{HEW}$ apparently invokes the rule that enumerated exceptions to a reinedial statute are deemed to be exclusive. ${ }^{56}$ The North Haven court declined to adopt either the courts' or HEW's positions, choosing instead to examine Title IX's legislative history to determine the intent of Congress in creating the exceptions. 57

An analysis of the purpose and effects of the exceptions indicates that Congress did intend section 901 to prohibit discrimination against both students and einployees. During the debates surrounding the enactment of Title IX, Senator Pell asked Senator Bayh about section 901's exceptions and about whether elementary and secondary schools would be covered. Senator Bayh replied:

At the elementary and secondary levels, admissions policies are not covered. ... [W]e are dealing with three basically different types of discrimination lere. We are dealing with discrimination in admission to an institution, discrimination of available services or studies within an institution once students are admitted, and discrimination in employment within an institution, as a member of a faculty or whatever.

In the area of employment, we permit no exceptions. In the area of services, once a student is accepted within an institution, we permit no exceptions. ${ }^{58}$

This exchange seriously undermines the Islesboro court's view that the wording of the exceptions indicates that Title IX was not designed to

52. Id.

53. 600 F.2d 581 (6th Cir.), cert. denied, 444 U.S. 972 (1979).

54. 600 F.2d at 584. For a criticism of the Romeo court's assertion, see North Haven Bd. of Educ. v. Hufstedler, 629 F.2d 773, 778 (2d Cir. 1980), cert. granted sub nom. North Haven Bd. of Educ. v. Bell, 101 S. Ct. 1345 (1981).

55. See, e.g., 629 F.2d at 778.

56. See, e.g., Colorado Pub. Interest Research Group, Inc. v. Train, 507 F.2d 743, 747 (10th Cir. 1974) ("[W] are not favored'), rev'd on other grounds, 426 U.S. 1 (1975) (relying on a legislative history clearly indicating that Cougress did not intend the plain meaning of the language of the statute in question to be applied).

57. 629 F.2d at 778.

58. 118 CoNG. Rec. 5812 (1972) (remarks of Sen. Bayh) (emphasis added). 
cover employment practices. ${ }^{59}$ The exceptions merely allow specific kinds of discrimination against students ${ }^{60}$ or except entire categories of institutions from Title IX.61

Moreover, an examination of the exceptions themselves suggests that they fail to mention employees simply because they are inapplicable to employees. For example, one broad exception applies to admissions policies of "any public institution of undergraduate higher education which is an institution that traditionally and continually from its establishment has liad a policy of admitting only students of one sex."62 In addition, a six-year exception was created for the admissions practices of any educational institution in the process of clianging from a single-sex to a dual-sex program. ${ }^{63}$ Botli of these exceptions are expressly directed towards admissions and are thus inapplicable to employment. Though Congress apparently believed that compelling reasons existed for permitting discrimination against students to continue im these limited situations, ${ }^{64}$ there is no similar justification for allowing the imstitutions to continue to discriminate against faculty members and other employees. 65

Although none of the nine exceptions expressly inentions einployees, two were designed solely to permit einployinent discrimination in limited situations, further indicating that Title IX was generally intended to apply to einployment discrimination. With respect to parochial scliools ${ }^{66}$ and military scliools, ${ }^{67}$ Congress was concerned that prohibiting discrimination in hiring would destroy a crucial quality of the scliools. ${ }^{68}$ Accordingly, Congress excepted parochial schools from Title IX to permit the continued hiring of nuns as teachers, ${ }^{69}$ and mili-

59. See text accompanying note 52 supra. The North Haven court relied on Senator Bayh's statement, see text accompanying note 58 supra, to support its position. 629 F.2d at 781-82. There is some debate over whether Senator Bayh was referring to section 901 or to the amendments to Title VII and the Equal Pay Act. See text accompanying notes 105-13 infra.

60. E.g., 20 U.S.C. $\$ 1681(\mathrm{a})(2)$ (1970). See note 50 supra.

61. 20 U.S.C. $\$ 1681(a)(3)$-(4) (1976). See note 50 supra.

62. 20 U.S.C. $§ 1681(\mathrm{a})(5)$ (1976). See note 50 supra.

63. 20 U.S.C. \& $1681(\mathrm{a})(2)$ (1976). See note 50 supra.

64. See 118 CoNG. Rec. 5807, 5813-14 (1972) (remarks of Sen. Bayh). For example, Congress recognized that schools in a transition period froin a single-sex system to a dual-sex system would need time to adjust in order to minimize disruption.

65. Id. Where there was uncertainty about the effect of the regulation of employment practices, the institutions were exempted completely pending further study of the situation. Id. 5808 . See notes $89-97$ infra and accompanying text.

66. 20 U.S.C. § 1681(a)(3) (1976). See note 50 supra.

67. 20 U.S.C. § 1681(a)(4) (1976). See note 50 supra.

68. See 118 CONG. REC. 5807, 5813-14 (1972) (remarks of Sen. Bayh).

69. Id. 5813. 
tary schools to permit the continued hiring of inale faculties. ${ }^{70} \mathrm{Had}$ Congress intended these exceptions to affect only admissions policies, the exception for traditionally one-sex schools would have covered these institutions; ${ }^{71}$ no additional exception would have been necessary. ${ }^{72}$ Instead, Congress granted a full exception for the entire institution in order to accoinplish an additional goal: to guarantee that section 901 would not affect the hiring practices of the exeinpted institutions. ${ }^{73}$ In a discussion of the Title IX exemptions of parochial and military schools, Senator Bayh confirmed this interpretation. He concluded that a private school for females or a private school for males could inaintaim a single-sex student body, but that the schools would be subject to the sanctions of section 901 if they discriminated against faculty inembers on the basis of sex. Only their admissions practices would be excepted. ${ }^{74}$ Conversely, he noted that parochial and military schools could maintain a single-sex faculty because of the institutional exceptions created to maintain the traditions and functions of these special schools. ${ }^{75}$ As the North Haven court explained, the exceptions for parochial and military schools make no sense unless einployinent practices colne within the scope of section $901 .{ }^{76}$ Congress's decision to exempt some institutions completely so that they could contimue to maintain single-sex faculties ${ }^{77}$ strongly suggests that Congress intended to regulate the employment practices of all other institutions under section 901.

70. Id.

71. 20 U.S.C. $\S 1681(a)(2)$, (5) (1976). See note 50 supra.

72. The legislative history indicates that the reason for giving an institutional exemption to parochial and military schools was to allow further investigations into the feasibility of regulating these institutions. See 118 CoNG. ReC. 5807 (1972) (remarks of Sen. Bayh). Another possible reason for creating an exemption for an institution rather than exempting only its admissions policy is to allow the institution to discriminate against a student once he or she is accepted. A school that is permitted to discriminate in admissions would not be permitted to discriminate against a student on the basis of sex once he was admitted. Id. 5812. Senator Bayli explained that "[o]nce a student is accepted within an institution, we permit no exceptions." Id. An institution that is completely excepted, however, is not subject to section 901 and can presumably discriminate freely against students in the administration of services. This possibility seems implausible, however, because one of the the undisputed purposes of Title IX was to prevent discrimination against students. See Islesboro School Comm. v. Califano, 593 F.2d 424 (1st Cir.), cert. denied, 444 U.S. 972 (1979).

73. See 118 ConG. Rec. 5813-14 (1972) (remarks of Sen. Bayh). See note 72 supra.

74. 118 CoNG. REC. 5813-14 (1972) (remarks of Sen. Bayl).

75. Id. 5814.

76. See 629 F.2d at 782.

77. See 118 CONG. REC. 5813-14 (1972) (remarks of Sen. Bayh). 


\section{A Comparison of Title VI and Title IX.}

The language of section 901 of Title IX $^{78}$ is virtually identical to that of section 601 of Title VI. ${ }^{79}$ Such a close similarity merits construing the two provisions identically, ${ }^{80}$ using interpretations of phrases in Title VI to interpret similar phrases in Title IX. Recognizing the uncertainty about whether section 601 reached employment discrimination, Congress expressly excluded einployment discrimination froin Title VI. ${ }^{81}$ Congress did not, however, make a similar exclusion for employment in section 901 of Title IX. This omission, as HEW has consistently urged, imphies that Congress intended Title IX to have broader applicability than Title VI. Indeed, courts frequently attach significance to inajor differences in the language of two otherwise identical statutes. 82 As the North Haven court noted, "although Title IX is inodeled after Title VI . . . Title IX conspicuously omits Title VI's exclusion of employment practices . . ..."83

In the original House version of Title IX, section 904 specifically excluded einployment, ${ }^{84}$ but the House receded in committee. ${ }^{85}$ A1though HEW and the Departinent of Education have asserted that this

78. See text accompanying note 2 supra.

79. Civil Rights Act of $1964, \S 601,42$ U.S.C. $\$ 2000$ d (1976), which provides: 'No person in the United States shall, on the ground of race, color, or national origin, be excluded from participation $\dot{\mathrm{n}}$, be denied the benefits of, or be subjected to discrimination under any program or activity receiving Federal financial assistance."

80. The doctrine of in pari materia stems from practical experience in interpreting statutes. Courts recognize that a "legislative body generally uses a particular word with a consistent neaning in a given context." Erlenbaugh v. United States, 409 U.S. 239, 243 (1972). Accordingly, two statutes using the same or similar language that cover the same general subject area should be construed in pari materia, and the previously interpreted language nay be used to construe identical language in the other, later statute. Id. at 243-44; 2A J. SUTHERLAND, supra note $40, \S 51.03$.

81. 42 U.S.C. $\$ 2000 d-3$ (1976), which provides: "Nothing contained in this subchapter shall be construed to authorize action under this subchapter by any department or agency with respect to any employment practice of any employer, eniployinent agency, or labor organization except where a primary objective of the Federal financial assistance is to provide employnent." See Hearings, supra note 49, at 379 (reniarks of Rep. Poff that the broad language of Title V1 could encompass employees); 110 CONG. REC. 2484 (1964) (remarks of several congressnien discussing Title VI and employinent); $i d$. 12,707 (reinarks of Sen. Humphrey about the confusion surrounding Title VI and employinent).

82. See Klein v. Republic Steel Corp., 435 F.2d 762, 765-66 (3d Cir. 1970) ("It is a canon of statutory construction that where as here the words of a later statute differ front those of a previous one on the same or a related subject, the legislature nuust have intended then to have a different nueaning”); Western States Newspapers, Inc. v. Gehringer, 203 Cal. App. 2d 793, 799, 22 Cal. Rptr. 144, 148 (1962) ("Where a statute, with reference to one subject contains a given provision, the omission of such provision from a similar statute concerning a related subject . . . is significant to show that a different intention existed").

83. $629 \mathrm{~F} .2 \mathrm{~d}$ at 778.

84. H.R. REP. No. 7248, 92d Cong., 1st Sess. (1971). The proposed section 904 provided: "Nothing contained in this title shall be construed to authorize action under this title by any department or agency with respect to any employinent practice of any employer, employinent 
deletion shows that the House intended Title IX to cover employment practices, ${ }^{86}$ it is now clear that the initial inclusion of section $904 \mathrm{~m}$ the House bill was in fact merely a drafting inistake; ${ }^{87}$ drafters inadvertently included section 904 and then siniply deleted the section upon discovering their error. ${ }^{88}$ While this mistake explains how section 904 came to be included in the first instance, it does not explain what Congress actually intended the scope of Title IX to be.

As origmally introduced, the bill that contamed Title IX also contained amendments to the Equal Pay Act ${ }^{89}$ and Title VII of the Civil Rights Act of 1964.90 These proposed amendments extended the coverage of both acts to einployees of educational institutions.91 One commentator ${ }^{92}$ and several courts ${ }^{93}$ have asserted that section 904 was included by mistake and deleted in order to inaintain internal consistency within the entire bill: a section expressly excluding einployment practices froin Title IX would have been inconsistent with the proposed

agency, or labor organization except where a primary objective of the Federal financial assistance is to provide employment."

85. The House committee conference report states:

[T] he House amendment, but not the Senate amendinent, provided that nothing in the title authorizes action by any department or agency with respect to any employment practice of any employer, einployinent agency, or labor organization except where a primary objective of the Federal financial assistance is to provide employment. The House recedes.

H.R. REP. No. 554, 92d Cong., 1st Sess., reprinted in [1972] U.S. CoDE CoNG. \& AD. NEWs 267172.

86. HEW advanced this argument in, for example, North Haven Bd. of Educ. v. Hufstedler, 629 F.2d 773, 778 (2d Cir. 1980), cert. granted sub nom. North Haven Bd. of Educ. v. Bell, 101 S. Ct. 1345 (1981).

87. Kuhn, Hearings on Sex Discrimination Regulations Before the Subcomm. on Postsecondary Education of the House Comm. on Education and Labor, 94th Cong., 1st Sess. 466 (1975) [hereinafter cited as Hearings on Sex Discrimination Regulations]; Title IX: Employment and Athletics Are Outside HEW's Jurisdiction, 65 GEO. L.J. 49, $57-58$ (1976).

88. Note, Title IX Does Not Apply to Faculty Employment, 1981 DukE L.J. 566, 579-80. After explaining that Title IX was drafted by making a copy of Title VI and changing "race" to "sex" and that section 904 was inadvertently included, Representative O'Hara stated:

Now, great significance is being given to the fact that it [section 904] was dropped out. It was dropped out because it got in through a drafting error. So the quiet, easy way to get it out was to shide it out somewhere aloug the line without having to go through a

long explanation as to how it got in. So much for that part of the argument.

Hearings on Sex Discrimination Regulations, supra note 87, at 409.

89. 29 U.S.C. $\$ 213$ (a) (1976).

90. 42 U.S.C. $\$ 2000$ e (1976). The proposed amendment to Title VII was ultimately dropped because an amendment accoinplishing the same purpose was enacted as part of the Equal Employment Act of 1972, Pub. L. No. 92-261 § 2(1), 42 U.S.C. $\$ 2000 \mathrm{e}-2$ (1976).

91. 118 CONG. REC. 5802-03, 5815 (1972).

92. Kuhn, supra note 87 , at 57 .

93. Romeo Community Schools v. HEW, 600 F.2d 581, 584 (6th Cir.), cert. denied, 444 U.S. 972 (1979); Islesboro School Comm. v. Califano, 593 F.2d 424, 428 (1st Cir.), cert. denied, 444 U.S. 972 (1979). Contra, North Haven Bd. of Educ. v. Hufstedler, 629 F.2d 773, 783 (2d Cir. 1980), cert. granted sub nom. North Haven Bd. of Educ. v. Bell, 101 S. Ct. 1345 (1981). 
ainendments to Title VII and the Equal Pay Act. ${ }^{94}$ Notwithstanding the deletion of section 904, these authorities argue that Congress intended to exclude enployment practices from the scope of Title IX. This argument is inconsistent, however. It rehes on the drafting mistake theory to explain how section 904 was included, but also suggests that the section would have been retained had it not created an imconsistency. Yet the legislative history indicates that section 904 was reInoved solely because its inclusion was a drafting error. There is no evidence that it would have been retained if there were no internal consistency problems in the bill.

Applying this analysis, the problem of interpreting the language of Title IX by comparing it to Title VI becomes considerably less confusing. Title VI expressly excludes employment from its coverage; Title IX, as enacted, does not. Congress should have expected that interpretations of Title IX would reflect this difference in language. ${ }^{95}$ If Congress had intended Title IX to have the same meaning as Title VI with respect to employnent practices, it could easily have created an additional exception. As the North Haven court observed, Congress could have imserted a provision such as "[n]othing in $\S 901$ shall apply to any employee of any educational institution subject to this Title"96 if it had wanted Title IX to be interpreted like Title VI. Alternatively, Congress could have added another exception to those enumerated in section 901(a). ${ }^{97}$ Because Congress in fact did neither of these things, there remains good reason for interpreting Title IX differently from Title VI. Only Title IX has language broad enough to cover employees.

\section{The Legislative History of Tirle IX}

Understandably, the North Haven court decided that the language of Title IX is too ambiguous to offer a satisfactory interpretation of its intended scope. Accordingly the court looked to the legislative history of Title IX to decide whether Congress imtended to imclude employment practices within the scope of the statute. ${ }^{98}$ In particular, the court examined Senator Bayh's assertion that employment discrimination was an intended target of Title IX.99 Senator Bayh, before the enactment of Title IX, stated that "[S]ex discrimination reaches into all fac-

94. See Kuhn, supra note 87 , at 57-58.

95. See, e.g., Erlenbaugh v. United States, 409 U.S. 239, 243-44 (1972); Link-Simon, Inc. v. Muehleback Hotel, Inc., 374 F. Supp. 789, 794-95 (W.D. Mo. 1974).

96. $629 \mathrm{~F} .2 \mathrm{~d}$ at 783 .

97. The exceptions to Title IX are enumerated in 20 U.S.C. $\$ 1681(\mathrm{a})(1)-(9)(1976)$, which is reproduced in part in note 50 supra.

98. 629 F.2d at 778 .

99. Id. at 779 . 
ets of education-admissions, scholarship programs, faculty hiring and promotion, professional staffing, and pay scales." 100 He further explained that the Act "closes loopholes in existing legislation relatimg to general education programs and employment resulting from those programs . . . . The amendment would cover such crucial aspects as admissions procedures, scholarships, and faculty employment, with limited exceptions."101

These statements indicate that Senator Bayh believed that Title IX should coinbat sex discrimination against female students and faculty inembers. ${ }^{102}$ In addition, Senator Bayh's discussion of the enforcement mechanism chosen for Title IX's section 901 indicates that section 901 was intended to apply to employinent practices. Section 902 of Title IX has the unique remedy of fund withdrawal, ${ }^{103}$ and while explaining how this method of enforcement would discourage discrimination, Senator Bayh stated:

Failure to comply with the regulations may result in the termination of funding. . . . The effect of the termination of funds is limited to the particular entity and program in which such noncompliance has been found.

This portion of the amendinent covers discrimination in all areas where abuse lias been mentioned-employment practices for faculty and administrators, scholarship aid, admissions, access to programs within the institution such as vocational education classes, and so forth. The provisions lave been tested under Title VI . . f for the last 8 years so that we have evidence of their effectiveness and flexibility. ${ }^{104}$

100. 118 CoNG. Rec. 5803 (1972) (remarks of Sen. Bayh). Statistics on differences in salary levels, promotions, and educational opportunities illustrate the severity of the problem. Id. 5804. 05; Johnson \& Stafford, Women and the Academic Labor Market, in SEX Discrimination AND THE DIVISION OF LABOR 201 (1975). In the southern states there were extreme examples of discrimination against women seeking teaching positions. In Mississippi, the three districts surveyed had no female administrators. In the Oxford, Mississippi, school district, applicants for teaching positions were given a two page booklet labeled "Criteria for Employment." The booklet expressly stated that inen would be preferred over women. Similar situations existed in South Carolina, Louisiana, Alabama, and Arkansas. Southeastern Public Education Program of the american Friends Service Comm., Almost as Fairly: The First Year of Title IX ImpleMENTATION IN Six SoutheRn States 70-79 (1979).

101. 118 CoNG. REC. 5803 (1972) (remarks of Sen. Bayh). There is some debate over whether Senator Bayh was referring to Title IX or to the amendments to Title VII and the Equal Pay Act that were included in his bill. See text accompanying notes 89-91 supra. The North Haven court concluded that he was referring to Title IX. 629 F.2d at 782 . See text accompanyimg notes 105-13 infra.

I02. Regarding the weight given to the interpretation of a bill by its sponsor, see note 119 infra.

103. 20 U.S.C. $\$ 1682$ (1976). See text accompanying notes $127-41$ infra for a discussion of low Title IX's remedies fit into the framework of other remedies for einployment discrimination.

104. 118 CoNG. REC. 5807 (1972) (remarks of Sen. Bayli) (emphasis added). 
Apparently Senator Bayh beheved employment discrimination was one of the evils Title IX was meant to remedy.

Courts holding that HEW's regulations are invalid have given insufficient attention to the legislative history of Title IX. Arguing that each of Senator Bayli's stateinents about employment practices referred to the amendments to Title VII and the Equal Pay Act, ${ }^{105}$ contamed in the saine bill, and not to Title IX specifically, these courts have pointed out that Senator Bayh often spoke of the various enactments collectively and confused the boundaries of each. For example, the court in Brunswick School Board v. Califano noted that Senator Bayh's remarks "can only reasonably be understood as alluding to the Title VII and Equal Pay Act amendments, and not to § 901."106 Similarly, in Islesboro School Committee v. Califano 107 the court surmised: "[W]e think HEW's readimg is strained. We think this particularly in light of the fact that the discussion was an oral one and thus not as precise as a response in written form . . . ."108 The court concluded that "a careful examination of the debates has led us to conclude tliat these were the product of the imprecision of oral discussion ratlier than a reflection that the Act intended section 901 of Title IX to embrace prohibitions against sex discrimination in employment." 109 The North Haven court noted, however, that references to specific portions of Title IX are discermible. ${ }^{110}$ For example, Senator Bayh's discussion of the exceptions covering employment practices in military and parochial schools ${ }^{111}$ inust have referred to section 901 . The amendments to Title VII and the Equal Pay Act did not contain similar exceptions; thus these statements were inapplicable to them. Similarly, when Senator Bayh explamed how Title IX's fund-withdrawal provisions could help prevent einployment discrimination ${ }^{112}$ lie had to be referring to section 901 . Only Title IX contains that unique feature. ${ }^{113}$

Aside froin the fact that references to Title IX are clearly discermble, the premise that the debates are necessarily imprecise is unpersuasive for inore practical reasons. First, many of Bayh's statements were

105. See text accompanying notes 89-91 supra.

106. 449 F. Supp. 866, 873 (D. Me. 1978), affd sub nom. Islesboro School Comm. v. Califano, 593 F.2d 424 (1st Cir.), cert. denied, 444 U.S. 972 (1979).

107. 593 F.2d 424 (1st Cir.), cert. denied, 444 U.S. 972 (1979).

108. $593 \mathrm{~F} .2 \mathrm{~d}$ at 427.

109. Id. at 428.

110. 629 F.2d at 780 .

111. See text accompanying notes 66-77 supra.

112. See text accompanying notes 103-04 supra.

113. Title IX of the Education Amendments of $1972, \S 902,20$ U.S.C. $\S 1682$ (1976). 
prepared in advance, ${ }^{114}$ rather than uttered in the heat of debate where the possibility of misstatement is greater. Second, in his own interpretation of the debates Senator Bayh has consistently maintained that section 901 covers employment practices. ${ }^{115}$ The hearings conducted on the validity of HEW's regulations clarify his position and are the best indication of his imtentions.

After HEW promulgated its regulations for the enforcement of Title IX, Congress carefully scrutinized the regulations to decide if they were consistent with the Act.116 In prepared testimony, Senator Bayh presented his views about how the regulations captured the spirit of Title IX:

While the regulations are disappointing in some respects, on balance the regulations do make significant strides in mandating equality for women. The heart of these guidelines is the prohibition against the thwarting of equal opportumities for female students and teachers at any educational level.

The Title IX guidelines, as the Congress mandated, call for equality in admissions, financial aid, course offerings, career counseling, and in the case of teachers and other educational personnel, employment, pay and promotions. We have waited 3 full years already for implementing regulations. Therefore, I ain urging the Congress to adopt the regulations without any further delay. ${ }^{117}$

Senator Bayh elaborated on this statement orally, remarking that "[t]he heart of these guidelines is the prohibition against the thwarting of equal opportunities for female students and teachers at any educational level."118 As the sponsor of the legislation, Senator Bayh's views are entitled to significant weight, ${ }^{119}$ especially because there is no other

114. See Petitioner's Brief for Certiorari, supra note 8, at 17.

115. See text accompanying notes 117-20 infra.

116. See 20 U.S.C. $\$ 1232$ (d)(1) (1976), which provides that the regulations become effective unless Congress disapproves them as inconsistent with the Act. Representative O'Hara, chairman of the investigating committee, made it clear that the regulations would be subject to strict scrutiny. Speaking of the power vested in Congress under section 1232(d)(1), he stated:

For all too long, the bureaucrats have assumed that the duty of the Congress was simply to make general poticy and then to lean back and let the bureaucrats write the real law in the shape of regulations. And the Congress, for too many years, has been im the position of doing exactly that.

Section 431(d) [\$1232(d)(1)] says that the bureaucracy shall be held accountable and that its regulations will be scrutinized very carefully to see if they are consistent with the law from which they must draw all of their authority. The Congress, section 431 (d) says, will return to making the law and the bureaucrats can return to carrying it out the way it was intended to be carried out when it was enacted.

Hearings on Sex Discrimination Regulations, supra note 87, at 1-2.

117. Hearings on Sex Discrimination Regulations, supra note 87, at 169 (emphasis added).

118. Id. 173. Other members of Congress expressed similar views. E.g., id. 163-64 (remarks of Rep. Mink).

119. Legislators often look to the sponsor of a bill for information, because he is expected to be particularly well informed about the bill's purpose and intended effect. Courts therefore give 


\section{clear evidence of congressional intent. ${ }^{120}$}

After considering extensive testimony, ${ }^{121}$ both houses of Congress declined to adopt resolutions disapproving the regulations. ${ }^{122}$ In addition, Senators Helins and McClure each introduced amendments specifically removing einployinent practices froin the scope of Title IX. ${ }^{123}$ Neither anendment was adopted. The North Haven court, while agreeing with Islesboro that "[c]ongressional inaction should not be lightly construed as approval," 124 correctly concluded that "the congressional reaction to the Title IX regulations, in the context of the legislative history as a whole, lends some additional weight to the view

substantial weight to the sponsor's interpretations. See, e.g., Federal Energy Admin. v. Algonquin SNG, Inc., 426 U.S. 548, 564 (1976) ("as a statement of one of the legislation's sponsors, this explanation deserves to be accorded substantial weight in interpreting the statute"); United States v. Enmons, 410 U.S. 396, $405 \mathrm{n} .14$ (1973) (the sponsor's interpretation is entitled to consideration in delineating the scope of a statute); United States v. Oates, 560 F.2d 45, $69 \mathrm{n} .25$ (2d Cir. 1977) ("It is, of course, well-established that the sponsor's interpretation of his proposal, when expressed prior to adoption of the legislation, is entitled to great weight"); Gartner v. Soloner, 384 F.2d 348, 353 (3d Cir.) ("In attempting to extract the legislative purpose primary concern should always be given to the views expressed by the sponsors of the bill. . . . [These statements] should be looked to as representing the true spirit of [the law]"), cert. denied, 390 U.S. 1040 (1967).

120. The weight given the sponsor's views is limited if these statements contradict other clear indicia of legislative intent. See Chrysler Corp. v. Brown, 441 U.S. 281, 3I 1-12 (1979) (disregarding the sponsor's statements about the scope of the law in question because these stateinents were contrary to the legislative history, purpose, and logic of the statute).

121. See Hearings on Sex Discrimination Regulations, supra note 87.

122. Senator Helms, a vocal opponent of HEW's regulations, acted pursuant to 20 U.S.C. $\S 1232(d)(1)$ (1976) to disapprove the regulations. Helms objected to the regulations covering athletic activities, pregnant students and teachers, and einployees of educational institutions. With respect to the last category Helms stated: "While it was the obvious intent of the statute that it apply to those seeking an educational opportunity, the regulations cover the employees of educational institutions, whether they be maintenance personnel, administrative staff, or teaehers. Again the regulations are inconsistent with the Congressional enactment." 12I CoNG. REC. 17,301 (1975) (remarks of Sen. Helms).

Representatives Quie and Erlenborn submitted an amendment to disapprove the employment regulations. The amendment read: "Subpart $E$ [the einployment regulations] . . is inconsistent with the Act since by amendment to Title VII of the Civil Rights Act of 1964 and the Fair Labor Standards Act of 1938, Congress has conferred such jurisdictions upon the United States Equal Eunployment Opportunity Commission and the Department of Labor." Hearings on Sex Diserimination Regulations, supra note 87, discussed in North Haven Bd. of Educ. v. Hufstedler, 629 F.2d at 783 (referring to an unpublished amendment on file with that Committee).

123. Senator Helms's amendment contained several points. The nuajor changes advocated were that Title IX would not be construed to cover athletics and that "nothing in this section [section 901 of Title IX] shall apply to any employees of any educational institution subject to this title." 12I CoNG. ReC. 23,847 (1975). Senator MeClure atteinpted to amend section 90I by adding: "For purposes of this chapter, an educational program or activity means such programs or activities as are curriculun or graduation requirements of the institutions." 122 CONG. REC. 28,136 (1975).

124. North Haven Bd. of Educ. v. Hufstedler, 629 F.2d at 784 (quoting Islesboro School Comm. v. Califano, 593 F.2d 424, 428 n.3 (1st Cir.), cert. denied, 444 U.S. 972 (1979)). 
that $\S 901$ was expressly imtended to relate to employment practices." 125

The Supreme Court has recently noted that although "the views of subsequent Congresses cannot override the unmistakable intent of the enactimg one . . . such views are entitled to significant weight . . . and particularly so when the precise intent of the enactimg Congress is obscure." 126 Thus, even if the precise imtent of the Congress that enacted Title IX is determined to be obscure, Congress's later failure to disapprove the regulations or restrict the scope of Title IX permissibly helps define the intent of the Congress that origmally enacted Title IX.

\section{TItLe IX Remedies}

An examination of how Title IX fits into the general scheme of employment discrimination remedies provides further insight into its intended scope. Section 902 authorizes the Department of Education to terminate federal assistance to any program or activity found to be in violation of the Act. ${ }^{127}$ In addition, the Department of Education can obtain compliance by any other ineans authorized by law. ${ }^{128}$ These remedies are unique and serve as a supplement to existimg employment discrimination remedies.

Some commentators have argued that because Title VII and the Equal Pay Act were amended to cover the employment practices of educational imstitutions, ${ }^{129}$ it is unlikely that Congress also intended simultaneously to create a separate remedy for employment discrimination through Title IX.130 It is quite common in the area of employment discrimination to have several statutes proscribing similar conduct, however. ${ }^{131}$ Both Title VII ${ }^{132}$ and the Equal Pay Act ${ }^{133}$ regulate em-

125. 629 F.2d at 784 .

126. Seatrain Shipbuilding Corp. v. Shell Oil Co., 444 U.S. 572, 596 (1980); $c f$. Oscar Mayer \& Co. v. Evans, 441 U.S. 750, 758 (1979) (noting that the thoughts of Congress in 1978 about the intent of the 1967 Congress are "plainly insufficient to overcome clear and convincing evidence" of a contrary intent).

127. 20 U.S.C. $\$ 1682$ (1976).

128. $I d$.

129. See text accoinpanying notes 89-91 supra.

130. See, e.g., 1 A. Larson, Employment Discrimination, $§ 7.40$ (1980). Professor Larson pointed ont that

Probably the most cogent overall argument is the simple fact that in the very same enactment, Congress also extended Title VII to educational institutions, and it is hard to beheve that Congress, in a fit of absentmindedness, intended to create simultaneously two separate sets of laws, regulations, and administrations for employment discrimination by educational institutions.

Id. See note 25 supra and accompanying text.

131. See North Haven Bd. of Educ. v. Hufstedler, 629 F.2d at 785.

132. 42 U.S.C. $\$ 2000 \mathrm{e}(1976)$.

133. 29 U.S.C. $\& 213(\mathrm{a})(1976)$. 
ployment practices in educational institutions, ${ }^{134}$ for exainple, even though the entire scope of the Equal Pay Act is also covered by Title VII. ${ }^{135}$ It is not implausible that Congress intended to create an additional overlapping reinedy for einployinent discrimination in Title IX.

Indeed, overlapping statutes in this context are the norm rather than the exception. Section 715 of the Equal Einployment Act of $1972^{136}$ is illustrative. It created the Equal Einployinent Coordinating Council, coinposed of representatives of several government agencies and departinents that had jurisdiction in the labor regulation area. The purpose of the Council was to sort out the overlapping jurisdictions of the various agencies in an effort "to inaximize efforts, promote efficiency, and eliminate conflict, competition, duphcation and inconsistency among the operations, functions and jurisdictions of the various departments ...."137 This statute shows that Congress is well aware of the existence of coinciding remedies; therefore very little weight should be attached to Title IX's overlapping of other employment discrimination statutes.

Moreover, applying Title IX to reinedy employment discrimination violations would provide a needed supplement to other remedies. Title IX is far more comprehensive in scope than the Equal Pay Act, which requires only that all persons doing equal work receive equal pay. ${ }^{138}$ In addition, Title IX provides a more powerful remedy than Title VII when there are no money damages at stake. Under Title VII the most potent remedy available is an injunction against the employer. ${ }^{139}$ Under Title IX, however, the Department of Education has available the remedy of fund withdrawal without regard to whether there has been a monetary loss. ${ }^{140}$ The potential loss to the einployer is thus much greater if Title IX, rather than Title VII, is apphed. Thus Title IX gives the Department of Education considerable leverage in conciliation efforts; this leverage presumably will tend to reduce litigation and encourage voluntary compliance. ${ }^{141}$ If Title IX is successful in

134. Both statutes were extended to cover the employment practices of educational institutions as part of Title IX. 118 CoNG. REC. 5802-03, 5807 (1972). Only the amendment to the Equal Pay Act was ultimately enacted as part of Title IX $(\S 906(\mathrm{~b})(1))$, now codified as part of 29 U.S.C. $\S 213$ (a) (1976).

135. See Gunther v. County of Washington, 602 F.2d 882 (8th Cir. 1979), ccrt. granted, 49 U.S.L.W. 3332 (U.S. Nov. 3, 1980).

136. 42 U.S.C. $\$ 2000 \mathrm{e}-4$ (1976).

137. Id.

138. 29 U.S.C. \& 213(a) (1976).

139. See 42 U.S.C. $\$ 2000 \mathrm{e}-5(\mathrm{~g})$ (1976). See generally 2 A. LARSON, supra note 130 , $\$ 54.10$.

140. 20 U.S.C. $\$ 1682$ (1976). See North Haven Bd. of Educ. v. Hufstedler, 629 F.2d at 785.

141. A school systeen will probably be more willing to comply in a single case than to go to court and risk losing its federal funding. Under Title VII, on the other hand, schools might be 
achieving this goal, it will be an invaluable addition to the battery of remedies available to victims of employment discrimination-not merely another overlapping remedy.

\section{CONCLUSION}

Careful analysis of the language of Title IX, its legislative history and its remedies indicates that Congress intended Title IX to prohibit employment discrimination. The Court of Appeals for the Second Circuit has taken a long-needed step in North Haven by upholding the vahdity of HEW's regulations. The future effectiveness of Title IX depends on a reevaluation of the decisions invalidating HEW's implementimg regulations. Employment discrimination based on sex remaims a serious problem, and its victims are entitled to the added protection of Title IX, as Congress intended.

Terrence P. Collingsworth 